\title{
Diplomatic relations between the Spanish monarchy and the northern parts of the Holy Roman Empire during the reign of Charles II
}

\section{(Doctoral project)}

\author{
ONDŘEJ STOLIČKA
}

In the past, European historiography did not pay much attention to research on diplomatic relations between the Spanish monarchy and the northern parts of the Holy Roman Empire, especially during the reign of Charles II of Spain (1661-1700). In fact, there are no significant investigations of this period and this specific topic. The situation looks a little bit better in the field of historical investigation, which has focused on the connec- tions between Spain and Central Europe. However, this subject has never belonged to the main topics of Austrian, Czech, German, Hungarian, Polish or Spanish historiography. The prime reason for this lack of attention may be the result of the language barrier on both sides of Europe, ${ }^{1}$ and in patterns of historical development on this continent during the $20^{\text {th }}$ century. ${ }^{2}$ Despite these obstacles, a few historians were able to write on this topic during the

Czech historian Pavel Marek, in his article about the language barrier of Czech historians, mentioned this specifically, but is still necessary to mention that Spanish scholars also faced the same problem. To date, only a small number of them are able to use German language-documents. Pavel MAREK, Komunikace šlechticu mezi Prahou a Madridem v 16. a 17. století. Teze habilitační práce, in: Václav Bůžek (ed.), Šlechta raného novověku pohledem českých, francouzských a španělských historiků, České Budějovice 2009 (= Opera historica 13), p. 427.

2 Both Eastern and Western Europe were affected by an ideological influence of the totalitarian regime. In Spain, the themes connected with the Habsburgs were reserved especially by the Francoists and were used as a part of the state's propaganda. For more information about Spanish historiography and the research of the Habsburgs, see José Martínez Millán, La Dinastía Habsburgo en la historiografia española de los siglos XIX y XX, Librosdelacorte 7, 2013, p. 33-58. From the other side, we can note the example of Czech historiography, where the topics of the Habsburgs and Catholicism were connected with the big and strong role of the Battle of White Mountain in 1620. This battle has been reflected as a momentous defeat in Czech folklore. See more in Zdeněk HojDA, "Idola" barokního bádáni aneb jak se vyhnout Skylle a neupadnout v osidla Charybdy, in: idem (ed.), Kultura baroka v Čechách a na Moravě, Praha 1992, p. 15-26. Regarding the theme of the Battle of White Mountain, for example, see Josef Petráñ, Bitva na Bílé hoře podle současnébo stavu znalostí, Folia historica bohemica 8,1985, p. 109-134; IDEM, Na téma mýtu Bílá hora, in: Zdeňka Hledíková (ed.), Traditio et cultus: Miroslav Vlk archiepiscopo Pragensi ab eius collegis amicisque ad annum sexagessimum, Praha 1993, p. 141-162; Zdeněk Beneš, Bílá hora a české déjiny po čtyřiceti letech, in: František Kavka (ed.), Bílá hora a české dějiny, Praha 2003, p. 5-16. 
last century, and today inspire the work of new generations of scholars.

The first attempt by Czech historians who were researching Spanish connections to the history of their country in the early modern period addressed the mentioned relationships mainly from a political point of view. Antonín Gindely began to discover this part of the nations' common histories during the second half of the $19^{\text {th }}$ century. His published work was mostly regarding the question of the Counter-Reformation in Bohemia from the end of $16^{\text {th }}$ through the beginning of the $17^{\text {th }}$ centuries. ${ }^{3}$ During his life, Gindely also visited the General Archive in Simancas, Spain, where the main source for his research became the documents from the records of the Secretaría de Estado - Ale- mania (the German Secretary of State). ${ }^{4}$ Correspondingly, other Czech scholars, such as Josef Borovička, ${ }^{5}$ Vlastimil Kybal ${ }^{6}$ and Bohdan Chudoba, ${ }^{7}$ also proceeded to study the diplomatic sources and attached great importance to the materials in Simancas. ${ }^{8}$

In particular, Spain and the Empire 1519-1652, by Bohdan Chudoba, remains a very important study in this field. The book not only brought to light new political information, but also a new focus of attention on the influence of Spanish culture in Bohemia (in terms of clothing, books and paintings). An interesting part of Chudoba's study was his introduction of the most powerful noble families from Bohemia who were connected to the Spanish monarchy (the Pernstein,

3 Antonín Gindely, Déjiny českého poustání léta 1618 I-IV, Praha 1870-1880; IDEM, Geschichte der Gegenreformation in Böhmen, Leipzig 1894; IDEM, Rudolf II. und seine Zeit, Prag 1863.

4 For more information, see Archivo General de Simancas. Catálogo II. - Segretoria de Estado, Madrid 1942; Vlastimil KyвaL, Über die Bedeutung; Julián PAz, Catalogo II. Secretaria de Estado (Capitulaciones noc la casa de Austria y papeles de las negociaciones de Alemania, Sajonia, Polonia, Prusia y Hamburgo), Archiv für österreichische Geschichte 103, 1913, p. 163-432.

5 Josef BorovičKa, Archiv v Simancasu - př́spèvek ke kritice zpráv španělských vyslanců, Zprávy Zemského archivu Království českého 3, 1910, p. 115-180.

6 Vlastimil Kyвal, Drobné spisy historické I. Z cest a archivů, Praha 1915; IDEM, Über die Bedeutung des General-Archivs zu Simancas für die neuere Geschichte Österreichs, Wien 1910, IDEM, Jindřich IV. a Evropa v létech 1609 a 1610: kritický rozbor pramenưv a literatury, Praha 1909. Or about his work in František HrватA, El historiador checo Vlastimil Kybal sobre España, Ibero-Americana Pragensia 25, 1991, p. 87-106.

7 The book by Bohdan Chudoba about the Battle of White Mountain was published in both English and Spanish: Bohdan CHudoba, Španělé na Bílé hoře, Praha 1945; IDEM, Spain and the Empire 1519-1652, Chicago 1952; IDEM, España y el Imperio (1519-1643), Madrid 1963, 1986. His other works: IDEM, Španělští diplomaté ve Francii za doby českého povstání, Český časopis historický 41, 1935, p. 269-293; IDEM, Roudnická politika. Zastoupeni renesančni politické védy v knihovnè českého státníka na rozhraní XVI. a XVII. století, Sborník historického kroužku 33, 1932, p. 49-54, 113-118 and 177-184.

8 Milada Polišens ká, 120 Años de Estudios Checos en El Archivo General de Simancas, Ibero-Americana Pragensia 16, 1982, p. 211-225; Dagmar Culková, Výzkum bohemik v zahraniči do roku 1939 organizovaný našimi archivy, Sborník archivních prací 39, 1979, p. 160-181. 
Dietrichstein and Popel de Lobkowicz families). However, Chudoba's own Catholicism affected his point of view. His religious beliefs modified his interpretation of the Battle of White Mountain, which he perceived as an important victory for the people of Bohemia over the German influence. ${ }^{9}$

Chudoba's book remains the mostused Czech source in this research area, because its author based his work on the strong quantity of different sources from the Czech archives of noble families and foreign documents. ${ }^{10}$ Beginning in the 1950s, Josef Polišenský followed in Chudoba's steps, and, later on, Bohumil Bad’ura joined him. Polišenský, a Czech historian, combined his good knowledge of foreign archives and his language skills with Czech sources to reconstruct the relationship between the Austrian and Spanish Habsburgs during the first part of the Thirty Years War, emphasising the issue of Spanish culture in Central Eu- rope. ${ }^{11}$ Bad'ura chose an opposite way and focused on a smaller portion of the early modern period, researching the political strategy of one noble family, the Dietrichsteins, who were closely connected to the Spanish court and the king. ${ }^{12}$ In the following years, which are commonly referred to as "the Normalisation in Czechoslovakia", Czech historians experienced a necessary redirection of their research from the history of Spain to the history of Latin America. The main reason for this shift can be attributed to the continuing government of Spanish General Francisco Franco, whom communists considered to be an archenemy of socialist Czechoslovakia. ${ }^{13}$

The Velvet Revolution of 1989 delivered new energy to Czech historiography, primarily with the opening of the state's borders. Of course, new technology helped as well with establishing new connections with Western Europe. However, the topic of the Spanish influence in Central Europe

9 A detailed analysis of his book can be found in František Kutnar - Jaroslav Marek, Přehledné dějiny českého a slovenského dëjepisectví, Praha 1997, p. 804-806; Bohumil Jiroušé, Křestanství jako orientační mezník Bohdana Chudoby, in: Dagmar Blümlová (ed.), Aloys Skoumal (1904-1988) v průsečíku cest české kultury 20. století, České Budějovice 2004, p. 130-135.

10 P. МareK, Komunikace šlechticů, p. 430.

11 Josef Pouıšenskŕ, Tragic Triangle. The Netherlands, Spain and Bohemia 1617-1621, Praha 1991; IDEM, The Thirty Years War, London 1971.

12 Bohumil BaĎura, La casa de Dietrichstein y España, Ibero-Americana Pragensia 33, 1999, p. 47-67; IDEM, Markýza de Mondejar I-II, Jižní Morava 40-41, 2004-2005, p. 81-108, 59-82; IDEM, Los Borja y el Reino de Bohemia, Ibero-Americana Pragensia 39, 2005, p. 43-72; IDEM, Los intereses económicos de los Dietrichstein en España en los siglos XVI-XVIII, in: Josef Opatrný (ed.), Las relaciones checo-españolas, Praga 2007, p. 47-93 (= Ibero-Americana Pragensia, Supplementum 20); IDEM, Los paises checos y España: dos estudios de las relaciones checo-españolas, Praga 2006 (= Ibero-Americana Pragensia, Supplementum 16).

13 P. МAREK, Komunikace šlechticu, p. 430. This period saw the beginning of important synthetic works at the institute of Ibero-Americano in Prague examining the history of Latin America. Josef Polišenský (ed.), Déjiny Latinské Ameriky, Praha 1979. 
would have to wait, because Czech historians were more focused on reassessments of their own research, which was influenced by different points of view and new methodologies. ${ }^{14}$ Other, newer monographs have been published in the last few years. The first was a book by Czech scholar Josef Forbelský, who focused his attention mainly on the diplomatic history and foreign politics of Spanish kings Philip III and his son Philip IV. ${ }^{15}$ While Forbelský was following the life of General Baltasar de Marradas y Vique, a notable patron of the arts, he omitted to consider the cultural influence of the Spanish monarchy on Central Europe in the early modern peri- od, where he had many publications that he could use as sources for his own work. ${ }^{16}$ A second monograph, not yet mentioned, came from the significant $\mathrm{Czech}$ historian Pavel Marek. He asserted the importance of Czech historiography via his membership in Intituto Universitario „La Corte en Europa“ (IULCE). Marek's doctoral studies focused on the field of Bohemians' early modern history and how it connected with the Spanish world. The results of his research were published in the form of an edition of the matrimonial correspondence of $Z$ deněk Vojtěch, from the Lobkowicz family, and Polyxena Lobkowicz, from the Perstein. ${ }^{17}$ His

14 Václav BưžzK, Šlechta raného novověku v českém dějepisectví devadesátých let, in: Václav Bưžek Pavel Král (edd.), Aristokratické rezidence a dvory raného novověku, České Budějovice 1999 (= Opera historica 7), p. 5; Václav BŮžEK - Václav GrubHOFFer - Libor JAN, Wandlungen des Adels in den böhmischen Ländern, Bohemia 54, 2014, p. 285-287; Jiří KuBEš (ed.), Vyšši šlechta v českých zemich vobdobi baroka (1650-1750). Biogramy vybraných šlechticu a edice typických pramenü, Pardubice 2007, p. 10-12. Josef Forbelskŕ, Španělé, Říše a Čechy v 16. a 17. století. Osudy generála Baltasara Marradase, Praha 2006.

16 Regarding the general cultural connections between Bohemia and the Spanish monarchy, see, for example Jiří Lenz, Kulturni styky čsko-španělské v zrcadle dějin, Praha 1930; IDEM, Las relaciones culturales checo hispanas a través de la historia, Praga 1930; IDEM, Španělské kulturně-historické památky v Praze, Praha 1945. For more about the influence of Spanish art in Bohemia during the early modern period, see Eva BuкоцsкÁ - Pavel Štěpánek, Španělské podobizny, Praha 1980; Pavel Štěpánek, Španělské umění 14.-16. století, Praha 1985; IDEM, Španělské umění 17. a 18. století z československých sbírek, Praha 1989; IDEM, Španělské umělecké řemeslo 1550-1650, Praha 1997. On the influence of Spanish clothing, see Ludmila Kyвalová, Déjiny odivaání. Renesance (15. a 16. století), Praha 1996; IDEm, Dëjiny odiváni. Barok a rokoko, Praha 1996; Milena HajnÁ, ,Premáticas de los vestidos" aneb Královská nařizeni o odivuání a módè v renesančním Španèlsku, Miscellanea oddělení rukopisů a starých tiskủ Národní knihovny České republiky 16, 1999-2000, p. 189-208; EADEM, Moda al servicio del poder. La vestimenta en la sociedad noble de la Europa Central en la Edad Moderna y las infuencias de España, in: Actas de las XIII Jornadas Internacionales de historia del Arte. Arte, Poder y Sociedad en la España de los siglos XV a XX, Madrid 2008, p. 71-82; EADEM, Spanish Fashion in the Kingdom of Bohemia under Rudolf II (1552-1612), in: Jose Luis Colomer - Amalia Decalzo (edd.), Spanish Fashion at the Courts of Early Modern Europe I, Madrid 2014, p. 213-233; EADEM, Móda ve službách moci. Španělská móda a urozená společnost ve ceských zemich raného novověku, Olomouc 2015 ( $\mathrm{PhD}$ thesis).

17 Pavel Marek (ed.), Svèdectví o ztrátẽ starého svèta. Manželská korespondence Zdeňka Vojtěcha Popela z Lobkovic a Polyxeny Lobkovickéz Perštejna, České Budějovice 2005 (= Documenta res gestas Bohemicas saeculorum XVI. - XVIII. illustrantia B/1). 
latest work has focused on the Spanish embassy in Prague during the second half of the $16^{\text {th }}$ century and the first half of the $17^{\text {th }}$ century. ${ }^{18}$ This book analyses the role of the Spanish ambassadors who resided at the court of the Austrian Habsburgs in Prague and who, in this way, functioned as an important connection to the royal court in Madrid. However, his main objects of interest have not only been the ambassadors themselves, but also their patronage strategies. $\mathrm{He}$ has proven a strong interconnection between the Spanish embassy and a few noble Bohemian families who supported Spanish interests. Marek's monograph reflects the most modern methodology (new political history), and European historians have used it for the study of early modern diplomacy. This very important point of view uncovers the background of European politics during the $16^{\text {th }}$ and $17^{\text {th }}$ centuries, a perspective previous researchers have overlooked.

Similarly to Czech historians, German and Austrian scholars began researching their nations' mutual connections with the Spanish monarchy in the early $20^{\text {th }}$ century. The first monograph on the subject was written by Heinrich Günter and published in the year $1908 .{ }^{19}$ Its main asset was the registry of sources from the General Archive in Simancas, which, with its thoroughness, surpassed other, newer books. The second published work from the early $20^{\text {th }}$ century came from historian Otto Gliss, who focused his research on the juridical act of the Oñate Treaty of $1617 .{ }^{20}$ Both publications can serve as typical examples of positivist historiography in German-speaking countries at the beginning of the $20^{\text {th }}$ century.

In the middle of the $20^{\text {th }}$ century, Grete Mecenseffy published her research

18 Idem, La embajada española en la corte imperial (1558-1641), Figuras de los embajadores y estrategias clientelares, Praga 2013 (= Ibero-Americana Pragensia, Supplementum 33). His other works, for example, IDEM, La diplomacia española y la papel en la corte imperial de Fernando II, Studia historica. Historia Moderna 30, 2008, s. 109-143; IDEM, ¿Aliados o rivales? Apuntes sobre la colaboración política entre los embajadores españoles y los nuncius apostólicos en la corte imperial en la primera mitad del siglo XVII“, Ibero-americana pragensia, Supplementum 22, 2008, p. 27-43; IDEM, Luisa de las Llagas. La abadesa de las Descalzas y el proceso de la comunicación política y cultural entre la corte real española y la imperial, Pedralbes: revista d'história moderna 31, 2011, p. 47-90; IDEM, Patronagepolitik der spanischen Könige Philips II. und Philips III. am Prager Kaiserhof, in: David Schriffl - Niklas Perzi (edd.), Schlaglichter auf die Geschichte der Böhmischen Länder vom 16. bis 20. Jahrhundert. Ausgewählte Ergebnisse zu den österreichisch-tschechien Historikertagen 2006-2008, Wien-Berlin 2011, p. 37-44; IDEM, Zdenco Adalbert Popel von Lobkowitz die Laufbahn eines spanischen Klienten am Kaiserhof, in: Ronald G. Asch - Václav Bůžek - Volker Trugenberger (edd.), Adel in Südwestdeutschland und Böhmen 1450-1850, Stuttgart 2013 (= Veröffentlichungen der Komission für geschichtliche Landeskunde in Baden-Württemberg, Reihe B, Band 191), p. 37-57; IDEM, Španělská strana na císařském dvoře? K probematice jednoho pojmu z politických dějin, Český časopis historický 113, 2015, p. 965-990.

19 Heinrich Günter (ed.), Die Habsburger-Liga 1625-1635. Briefe und Akten aus dem General-Archiv zu Simancas, Berlin 1908.

20 Otto GLiss, Der Oñatevertrag, Frankfurt am Main 1930. 
on the relationships between the Austrian and Spanish Habsburgs during the Thirty Years' War. ${ }^{21}$ However, the most important publication of the time was by the Berliner historian Eberhard Straub. ${ }^{22}$ Similar to the Czech scholar Josef Polišenský, Straub focused his attention on the foreign affairs of the Spanish Habsburgs in Central Europe from 1617 to 1635 . A second significant German historian, Dieter Albrecht, in contrast, analysed the relationship between the Spanish monarchy and the Elector of Bavaria, Maximilian I (1573-1651). ${ }^{23}$ The works of Anna Egler ${ }^{24}$ and Jürgen Kessel ${ }^{25}$ also contributed greatly to this field of history. Egler researched the Spanish relationships to the Rhineland-Palatinate, while Kessel published an analysis of the connection between the Spanish Empire and the Electorates of Cologne, Mainz and Trier during the first half of the $17^{\text {th }}$ century. Hildegard Ernst accomplished the last work from this group of German historians with his study of the financial connections between Philip IV and Ferdinand II from the years 1632 to $1637 .{ }^{26}$

During the second half of the $20^{\text {th }}$ century, a group of researchers at the University of Vienna published a thematic series of works related to Spanish-Austrian relations. ${ }^{27}$ Under the tutelage of Friedrich Edelmayer and Alfred Kohler, scholars completed many enriching studies and editions in this research field. ${ }^{28}$ Another important work about cultural transfer in Central Europe came from the historian Bianca Maria Lindorfer. ${ }^{29}$ Analogous as

21 Grete Mecenseffy, Habsburger im 17. Jahrbundert. Die Beziehungen der Höfe von Wien und Madrid während des Dreissigjährigen Krieges, Archiv für österreichische Geschichte 121, 1955, p. 1-91; EADEM, Im Dienste dreier Habsburger: Leben und Wirken des Fürsten Johann Weikhard Auersperg (1615-1677), Wien 1950.

22 Eberhard Straub, Pax et Imperium. Spaniens Kampf um seine Friedensordnung in Europa zwischen 1617 und 1635, Paderborn 1980.

23 Dieter Alb recht, Die auswärtgie Politik Maximilians von Bayern 1618-1635, Göttingen 1962.

24 Anna Egler, Die Spanier in der linksrheinischen Pfalz 1620-1632, Mainz 1971.

25 Jürgen Kessel, Spanien und die geistlichen Kurstaaten am Rhein während der Regierungszeit der Infantin Isabella: (1621-1633), Frankfurt am Main 1979.

26 Hildegard Ernst, Madrid und Wien 1632-1637. Politik und Finanzen in den Beziehungen zwischen Philipp IV. und Ferdinand II., Münster 1991.

27 The general name of series was Studien zur Geschichte und Kultur der Iberischen und Iberoamerikanischen Länder - Estudios sobre Historia y Cultura de los Países Ibéricos e Iberoamericanos.

28 Friederich Edelmayer - Alfred Kohler (edd.), Die Katholischen Könige, Maximilian I. und die Anfänge der Casa de Austria in Spanien, Wien-München 1993 (= Hispania-Austria 1); Friedrich EdELmayer - Arno Strohmayer (edd.), Die Korrespondenz der Kaiser mit Ihren Gesandten in Spanien. Briefwechsel 1563-1565, Wien-München 1997; Friedrich Edelmayer (ed.), Die Epoche Philipps II. (1556-1598), Wien-München 1999 (= Hispania-Austria 2); IDEM, Söldner und Pensionäre. Das Netzwerk Philipps II. im Heiligen Römischen Reich, Wien-München 2002; Friedrich Edelmaye R - Virginia León Sanz - José Ignacio Ruiz Rodriguez (edd.), Der Spanische Erbfolgekrieg, WienMünchen-Alcalá de Henares 2008. 
her work, other students of Edelmayer contributed with their theses on the connections between the Spanish and Austrian Habsburgs. Their main person of interest was the imperial ambassador to Madrid, Johann Khevenhüller, and his correspondence. ${ }^{30}$

Other institutions focused on researching the relationships between the Spanish Empire and the Holy Roman Empire in the early modern period. El Instituto Histórico Austríaco, in Madrid, led research on the influence of the Spanish military orders on the Imperial territory, and later on the diplomatic relationships between the Spanish monarchy and Central Europe after the War of the Spanish
Succession. ${ }^{31}$ This diplomatic direction was also represented from the Austrian Academy of Sciences by, for example, the research of Jan Paul Niederkorn, ${ }^{32}$ and from the University of Erfurt by Peer Schmidt, who analysed the reflection of the Spanish monarchy and Spaniards in anti-Spanish propaganda of the Thirty Years War. ${ }^{33}$

The research by Andrea Sommer-Mathis and Christopher F. Laferl into the cultural connections between the Spanish world and Central Europe in German and Austrian historiography should also be noted. Sommer-Mathis, an Austrian historian, has focused her works mainly on the fest, theatre and other

29 Bianca Maria Lindorfer, Cosmopolitan Aristocracy and the Diffusion of Baroque Culture: Cultural Transfer from Spain to Austria in the Seventeenth Century, Florence 2009 (PhD thesis); EAdem, Las redes familiares de la aristocracia austriaca y los procesos de transferencia cultural: entre Madrid y Viena, 1550-1700, in: Bartolomé Yun Casalilla (ed.), Las redes del Imperio. Élites sociales en la articulación de la Monarquía Hispánica, 1492-1714, Madrid 2009, p. 261-288.

30 Karin Hofer, Die Berichte von Johann Khevenhüller, kaiserlicher Gesandter in Spanien, an Rudolf II. (1589/1590), Wien 1997 (PhD thesis); Arthur Stromenger, Die Berichte Johann Khevenhüllers, des kaiserlichen Gesandten in Spanien, an RudolfII. 1598-1600, Wien 2001 (PhD thesis); Maria Stieglecker, Wir haben dein gehorsames schreiben empfangen: die Korrespondenz Rudolfs II. mit Johann Khevenhüller, seinem Gesandten in Spanien. 1595-1598, Wien 2002 (PhD thesis); Tatjana LeHner, Johann Kevenhüller - ein Diplomat am Ende des 16. Jahrhunderts: seine Briefe an RudolfII. 1591-1594, Wien 2007 ( $\mathrm{PhD}$ thesis).

31 Ana Mur i Raurell (ed.), Diplomacia secreta y paz. La correspondencia de los embajadores españoles en Viena Juan Guillermo Ripperda y Luis Ripperda (1724-1727) / Geheimdiplomatie und Friede. Die Korrespondenz der spanischen Botschafter in Wien Johan Willem Ripperda und Ludolf Ripperda (1724-1727), Madrid 2011.

32 Jan Paul Niederkorn, Die europäischen Mächte und der „Lange Türkenkrieg“ Kaiser Rudolfs II. (1593-1606), Wien 1993; IDEM, Die Berichte der päpstlichen Nuntien und Gesandten Spaniens und Venedigs am kaiserlichen Hof aus dem 16. und 17. Jahrhundert, in: Josef Pauser - Martin Scheutz Thomas Winkelbauer (edd.), Quellenkunde der Habsburgermonarchie (16.-18. Jahrhundert). Ein exemplarisches Handbuch, Wien-München 2004, p. 94-107 (= Mitteilungen des Instituts für österreichische Geschichtsforschung 44).

33 Peer Schмidt, Spanische Universalmonarchie oder "teutsche Libertet", Stuttgart 2001; IDEM, La unidad de la Casa de Austria, in: José Martínez Millán - Maria Antonietta Visceglia (edd.), La monarquía de Felipe III IV (Los Reinos), p. 1374-1408. 
ceremonies at the Habsburg court. ${ }^{34} \mathrm{On}$ the other hand, Laferl has analysed the literature of the $16^{\text {th }}$ century ${ }^{35}$ and published, along with historian Christina Lutter, an edition of the Spanish familial correspondence of Ferdinand I. ${ }^{36}$
As previously mentioned, this direction of historical research was not among the favourite topics of Spanish historiography prior to the late $20^{\text {th }}$ century. However, a few Spanish historians still reached interesting results during the time. ${ }^{37}$ The in-

34 Andrea Sommer-Mathis (ed.), El teatro descubre América. Fiestas y teatro en la casa de Austria, Madrid 1992; Eadem, Entre Viena y Madrid, el tándem Metastasio-Farinelli. Dirección artística, in: Margarita Torrione (ed.), España festejante. El siglo XVIII, Málaga 2000, p. 383-401; EAdEM, Spanische Festkultur am Wiener Kaiserhof. Ein Beitrag zum europäischen Kulturtransfer im 17. Jahrhundert, Früheneuzeit-Info 11,2000, N 1, p. 7-15; EADEM, La ópera y la fiesta Cortesana: los intercambios entre Madrid y la corte imperial de Viena, in: Álvaro Torrente - Emilio Casares Rodicio (edd), La ópera en España e Hispanoamérica: una creación propia, Madrid 2001, p. 293-316; EADEM, La imagen de Carlos $V$ en las fiestas y el teatro español de comienzos de la Edad Moderna, in: Alfred Kohler (ed.), Carlos V/ Karl V. 1500-2000, Madrid 2001, p. 641-654; EAdEM, Música y teatro en las cortes de Madrid, Barcelona y Viena durante el conflicto dinástico Habsburgo-Borbón. Pretensiones políticas y teatro cortesano, in: Antonio Álvarez-Ossorio Alvariño - Bernardo J. García García - Virginia León (edd.), La pérdida de Europa. La guerra de Sucesión por la Monarquía de España, Madrid 2007, p. 181-198; eAdem, Höfisches Fest zwischen Zentrum ud Peripherie. Am Beispiel der spanisch-österreichischen Hochzeitsfestlichkeiten in der Frühen Neuzeit, in: Carlos Buján López - María José Domínguez Vázquez (edd.), Centros y periferias en España y Austria: aspectos literarios y culturales, Bern 2009, p. 193-221; EADEM, Calderón y el teatro imperial de Viena, in: José Martínez Millán - Rubén González Cuerva (edd.), La Dinastía de los Austria. Las relaciones entre la Monarquía Católica y el Imperio II, Madrid 2011, p. 1965-1989; EADEM, Las relaciones dinásticas y culturales entre losdos linajes de la casa de Austria y su incidencia en la obra de Velázquez, in: Javier Portús Pérez (ed.), Velázquez y la familia de Felipe IV (1650-1680), Madrid 2013, p. 61-73.

35 Christopher F. LAfErl, "No ayuda a la tiranía Dios:" La justificación del imperio universal de los Habsburgo en el teatro español, in: José M. Díez Borque - Karl F. Rudolf (edd.), Barrocco Español y Austríaco. Fiesta y Teatro en la corte de los Habsburgo y los Austrias, Madrid 1994, p. 67-72; IDEM, „En tierra ajena... "Spanier in Wien zu Zeit Ferdinands I. (1522-1564), Wiener Geschichtsblätter 52, 1997, p. 1-14; IDEM, Die Kultur der Spanier in Österreich unter Ferdinand I. 1522-1564, Wien-KölnWeimar 1997; IDEM, Konzeptismus und Theologie im barocken Spanien. Zur religiösen Lyrik Góngoras, Frühneuzeit-Info 8, 1997, N. 1, p. 23-34.

36 Christopher F. LAferl - Christina Lutter (edd.), Die Korrespondenz Ferdinand I. Familienkorrespondenz IV. (1533-1534), Wien 2000.

37 Guillén de San Clemente (ed. Juan Jordán de Urríes de Ayerbe), Correspondencia inédita de don Guillén de San Clemente, embajador en Alemania de los Reyes de don Felipe II y III, sobre la intervención de España en los sucesos de Polonia y Hungría 1581-1608, Zaragoza 1892; Miguel Lasso dE LA VEgA y López de Tejada, La embajada en Alemania del Conde de Oñate y la elección de Fernando II rey de Romanos (1616-1620), Madrid 1929; Alfonso Falcó y de la Gándara, Príncipe Pío, La elección de Fernando IV, Rey de romanos. Correspondencia del III marqués de Castel-Rodrigo, Don Francisco de Moura durante el tiempo de su embajada en Alemania (1648-1656), Madrid 1929; Luis Pérez Bueno, Del casamiento de Felipe II con su sobrina Ana de Austria, Hispania 7, 1947, p. 372-416; Rafael Ródenes Vilar (ed.), Maximiliano de Austria, gobernador de Carlos V en España Cartas al emperador, Madrid 1963; IDEM, La política europea de España durante la Guerra de Treinta Años (1624-1630), 
terest and activity in this field of research has grown the last 15 years, as evidenced by the many studies completed during this time. Pablo Jiménez Díaz has analysed the cultural relationships between Spain and Bohemia. ${ }^{38}$ The Spanish historian focused his attention on researching the collections that belonged to the Holy Roman Emperor, Rudolf II, which he found during a stay at Charles University in Prague. However, he also gave space in his work to the artistic sponsorship of the noble families from Bohemia (the Persteins, Dietrichsteins and Lobkowiczes). Another Spanish historian, Xavier Sellés Ferrando, has also studied the artistic connections between the Spanish world and Central Europe. ${ }^{39}$ His work, in comparison with Jiménez Díaz's, revealed this relationship over a longer period of time (from the Middle Ages to the present day). While his publication also covered a wide thematic space, from the Harrachs' art collection to the activities of Spanish soldiers in Central Europe and the influence of Spanish court ceremonies on the Austrian Habsburgs', his popular book still did not bring a new point of view.

The editions from Miguel Nieto Nuño and Félix Labrador Arroyo are especially significant for the research of the connections between the Spanish world and Central Europe. ${ }^{40}$ Nieto Nuño has focused his attention on a truly important person at the Spanish royal court in Madrid, the imperial ambassador Franz Eusebius of Pötting. ${ }^{41}$ His diary from the years 1664 through 1674 uncovered not only political events of the European world, but also his social networks and social life at the court of the Spanish king Philip II. Labrador Arroyo brought to light the story of another imperial diplomat, Hans Khevenhüller, who was in the service of the Austrian Habsburgs. He has also researched the organisation of the court of Margaret Theresa of Spain and her time in Austria. ${ }^{42}$

Madrid 1967; Xavier Baró Queralt, De Catalunya a Flandes, Barcelona 1979 (PhD thesis); Jesús Gutiérrez (ed.), Don Francisco de Moncada, el hombre y el embajador, Selección de textos inéditos, Boletín de la biblioteca de Menéndez Pelayo 56, 1980, 1-4, p. 3-72.

38 Pablo Jiménez Díaz, El coleccionismo manierista de los Austrias entre Felipe II y Rodolfo II, Madrid 2001.

39 Xavier Sellés Ferrando, Spanisches Österreich, Wien 2004.

40 Félix Labrador Arroyo (ed.), Diario de Hans Khevenhüller, embajador imperial en la corte de Felipe II, Madrid 2001.

41 Miguel Nieto Nuño (ed.), Diario del conde de Pötting, embajador del Sacro Imperio en Madrid (1664-1674) I-II, Madrid 1990.

42 Félix Labrador Arroyo, Los oficios de la caballeriza de la reina Margarita de Austria (1599-1611), Ibero-Americana Pragensia 40, 2006, p. 65-90; IDEM, La organización de la Casa de Margarita Teresa de Austria para su jornada al Imperio, in: José Martínez Millán - María Paula Marçal Lourenço (edd.), Las Relaciones Discretas entre las Monarquías Hispana y Portuguesa: Las Casas de las Reinas (siglos XV-XIX) II, Madrid 2008, p. 1221-1267; IDEM, Die Ausgestaltung des Hofstaates Margarete Theresa von Spanien für ibren Brautzug ins Reich, in: Václav Bůžek (ed.), Šlechta raného novověku pohledem českých, francouzských a španělských historiků, České Budějovice 2009 (= Opera historica 13), p. 157-185. 
Ana Mur i Raurell has published an edition that tell of the other side of the diplomatic relationship between the Spanish monarchy and the Imperial court of the Austrian Habsburgs. She studied the two Spanish ambassadors to the imperial court in Vienna, Juan Guillermo Ripperda and Luis Ripperda, during the years 1724 to $1727 .{ }^{43}$ Similarly, Juan Carlos Galende Díaz later published an edition of correspondence from Maria of Austria, the wife of Holy Roman Emperor Maximilian II and the daughter of Charles $\mathrm{V}^{44}$ The mentioned publication brought forth interesting information about politics, religion and other events and included her letters to his brother
Philip II, Philip III or the Duque de Alba.

Though previous historians contributed to the progress of the research focused on the connections between the Spanish world and Central Europe in the early modern period, only a few Spanish historians have chosen this theme as their main field of professional interest in recent years. To this group of young scholars belongs Vanessa Cruz Medina, who is interested in the study of women members of the Dietrichstein family and their relations to the Spanish world..$^{45}$ Other Spanish researchers representing this direction of Spanish historiography are Luis Tercero Casado, ${ }^{46}$ Rubén González Cuerva ${ }^{47}$ and Laura de Educación, Burgos 2003, p. 523-534; EADEM, Manos que escriben cartas: Ana de Dietrichstein y el género epistolar en el siglo XVI, Literae. Cuadernos sobre Cultura Escrita 3-4, 2003-2004, p. 161-187; EADEM, Margarita de Cardona y sus hijas, damas entre Madrid y el Imperio, in: J. Martínez Millán - M. P. Marçal Lourenço (edd.), Las Relaciones Discretos II, p. 1267-1301; EADEM, ,,Y porque sale la Reyna a senar acabo, que es mi semana de serbir. "La vida en Palacio de la reina Ana, las infantas Isabel Clara Eugenia y Catalina Micaela en las cartas de Ana de Dietrichstein, in: María Victoria López Cordón - Gloria Franco (edd.), La reina Isabel y las reinas de España: realidad, modelos e imagen historiográfica, Madrid 2005, p. 427-445; EADEM, Ana de Dietrichstein y España, in: Josef Opatrný (ed.), Las relaciones checo-españoles, Praga 2007, p. 103-117 (= Ibero-Americana Pragensia, Supplementum 20); EADEM, Korespondence Anny z Ditrichštejna, agentky a informátorky své rodiny na madridském dvoře, in: V. Bůžek (ed.), Šlechta raného novověku, s. 127-156.

46 Luis Tercero CAsado, Westfalia inconclusa: España y la restitución de Frankenthal (1649-1653), in: J. Martínez Millán - R. González Cuerva (edd.), La Dinastía de los Austria, II, p. 1387-1420; IDEM, La jornada de la reina Mariana de Austria a España: divergencias y tensión protocolar en el seno de la Casa de Austria (1648-1649), Hispania 71, 2011, p. 639-664; IDEM, A Fluctuating Ascendancy: The "Spanish Party" at the Imperial Court of Vienna (1631-1659), Librosdelacorte.es. Monográfico 7, 2015, N. 2, p. 54-67.

47 Rubén González Cuerva, Cruzada y dinastía: las mujeres de la casa de Austria ante la larga guerra de Hungría, in: J. Martinéz Millán - M. P. Marçal Lorenço (edd.), Las Relaciones Discretas II, p. 1149-1187; IDEM, El prodigioso principe transilvano: la larga guerra contra los turcos (1593-1606) a través de las relaciones de sucesos, Studia historica - historia moderna 28, 2006, p. 277-299; IDEM,

Vanessa Cruz Medina, La educacón de las meninas en la corte de Felipe II. Algunos aspectos a través de 
Oliván Santaliestra. ${ }^{48}$ In particular, Oliván Santaliestra's work stands out, since she uses German sources. Her point of view is influenced by the methodology of gender studies, which she has used in studies about Mariana of Austria, queen mother of Charles II of Spain, and women agents from the Harrach family. To this group of notable younger historians, we can also add Rocío Martínez López, a doctoral student at Universidad Nacional de Educación a Distancia, who is focusing on the international relationships between the Spanish Empire and the Electorate of Bavaria and the second marriage of the Spanish king Charles II to Maria Anna of Neoburg. ${ }^{49}$
Many of the studies introduced here have raised interesting questions, but among them only a few can be used for doctoral research, because of their methodological attitudes toward research. The works of Austrian historian Friedrich Edelmayer and Czech historian Pavel Marek take their primary inspiration from the fields of sociology and anthropology. Both of these excellent works belong inside the direction of historical methodology, which has been developing since the 1970s and has been dubbed „new political history “. ${ }^{50}$ The main point of view of this approach is in the discovering of the social relationships and strategies of individual

Felipe II y el turco: La larga guerra de Hungría (1593-1598), Madrid 2007; José Martínez Millán - Rubén González Cuerva (edd.), La Dinastía de los Austria. Las relaciones entre la Monarquía Católica y el Imperio I-III, Madrid 2011.

48 Laura Oliván Santaliestra, Pinceladas políticas, marcos Cortesanos: el diario del conde Harrach, embajador, embajador en la corte de Madrid (1673-1677), Cultura escrita y sociedad 3, 2006, p. 113-132; EAdem, La dama, el aya y la camarera: Perfiles políticos de tres mujeres de la Casa de Mariana de Austria, in: J. Martínez Millán - M. P. Marçal Lourenço (edd.), Las Relaciones Discretos II, p. 1301-1357; IDEM, Mariana de Austria: Imagen, poder y diplomacia de una reina soberana, Madrid 2006; IDEM, Mariana de Austriaen la encrucijada politica del siglo XVII, Madrid 2006 ( $\mathrm{PhD}$ thesis), IDEM, The Countess of Harrach and the Cultivation of the Body between Madrid and Vienna, in: Joan Lluís Palos - Magdalena Sánchez (edd.), Early Modern Dynastic Marriages and Cultural Transfer, Farnham-Burlington 2015, p. 213-234.

49 Unfortunately, her work is still in progress, though to date she has made a few conference presentations; for example: Between France, Bavaria and the Empire. Queen Mariana of Neuburg's power struggles and international negotiation related to Charles II's succession 2014, at the conference „Premodern Queenship and Diplomacy in Europe“, held at Canterbury Christ Church University in 2014; Queen Maria Anna and the Pfalz-Neuburg Dynasty: the influence of the Palatinate dynasty's interests in the court of Madrid in the context of Charles II of Spain's succession, Winchester 2014. However, her main topic of focus is the period of Charles II of Spain. She has published another article on the marriage of Holy Roman Emperor Leopold I. Rocío MARTínez Lopéz, La infanta se ha de casar con quien facilite la paz o disponga los medios para la guerra. Las negociaciones para la realización del mat rimonio entre la infanta María Teresa y Leopoldo I (1654-1657), Revista de Historia Moderna. Anales de la Universidad de Alicante 33, 2015, p. 79-99.

50 For more about new political history, see Andreas Hillgruber, Politische Geschichte in moderner Sicht, Historische Zeitschrift 216, 1973, p. 529-552; Hans-Ulrich WeHLer, Moderne Politikgeschichte oder „Große Politik der Kabinette"?, Geschichte und Gesellschaft 1, 1975, p. 344-369; Klaus Hildebrand, Geschichte der „Gesellschaftsgeschichte“. Die Notwendigkeit einer politischen Geschichts- 
persons who sought the division of power in the early modern age. At that time, the ruling courts were perceived as the main seats of power, so they were where the contemporary elites created mutual social networks based on patronage, clientelism and factionalism.

The works of David Starkey are the most famous representations of AngloSaxon historiography. He posited the notion that power is connected to individual institutions, so he focused his studies on individuals with access to power. ${ }^{51}$ In later years, Linda Levy Peck continued in this way on the themes of corruption and patronage in early Stuart England. ${ }^{52} \mathrm{Hi}-$ storians from Central Europe had similar interests, especially those from Germany, such as Ronald G. Asch ${ }^{53}$ and Wolfgang Reinhardt ${ }^{54}$ who developed the studies of non-institutional communication in the early modern period. Reinhardt introduced new terms on which social relationships could be based. During his research

schreibung von den internationalen Beziehungen, Historische Zeitschrift 223, 1976, p. 328-357;

Karl-Georg FABER, Ausprängungen des Historismus, Historische Zeitschrift 228, 1979, p. 1-22; Hans Mommsen, Politische Geschichte, in: Klaus Bergman (ed.), Handbuch der Geschichtsdidaktik I, Düsseldorf 1979, p. 141-145; Hans-Ulrich Thamer, Politische Geschichte, Geschichte der internationalen Beziehungen, in: Richard van Dülmen (ed.), Das Fischer Lexikon Geschichte, Frankfurt am Main 1990, p. 52-65; Barbara Stollberg-Rilinger (ed.), Was heißt Kulturgeschichte des Politischen?, Berlin 2005; Ute Frevert - Heinz-Gerhard Haupt (edd.), Neue Politikgeschichte: Perspektiven einer historischen Politikforschung, Frankfurt am Main 2005.

51 David Starkey (ed.), The English Court from the Wars of the Roses to the Civil War, London-New York 1987, p. 5.

52 Linda Levy Peck, Court, Patronage and Corruption in Early Stuart England, London 1993. This book became the inspiration for this type of research in Spain for historians from Universidad of Autonoma de Madrid. José Martínez Millán (ed.), Instituciones y Élites del Poder en la Monarquía Hispana durante el Siglo XVI, Madrid 1992; IDEM (ed.), La corte de Felipe II., Madrid 1994. Theoretical works, for example José Martínez Millán, La corte de La Moarquía hispánica, Studia historica - Historia Moderna 28,2006, p. 17-61; Felix Labrador Arroyo, Nueva historia politica: discurso y práctica del poder, in: Eliseo Serrano (ed.), De la tierra al cielo. Líneas recientes de investigación en Historia Moderna. Actas del 1 Encuentro de jóvenes investigadores en Historia Moderna, Zaragoza 2013, p. 11-51.

53 Ronald G. Asch - Adolf M. Birke (edd.), Princes, Patronage, and the Nobility: The Court at the Beginning of the Modern Age, c. 1450-1650, London 1991; Ronald G. Asch, Der Hof Karls I. von England. Politik, Provinz und Patronage 1625-1640, Köln-Weimar-Wien 1993; IDEM, Der englische Königshof im frühen 17. Jahrhundert im Spannungsfeld zwischen monarchischer Selbstdarstellung und Adelskultur, in: Václav Bůžek - Pavel Král (edd.), Aristokratické rezidence a dvory v raném novověku, České Budějovice 1999 (= Opera historica 7), p. 71-96; Pavel MAREK, Klientelni strategie španèlských králu na pražském císařském dvoře konce 16. a počátku 17. století, Český časopis historický 105, 2007, s. 40-89; José Ignacio Gómez Zorraquino, Patronazgo y clientelismo. Instituciones y ministros reales en el Aragón de los XVI y XVII, Zaragoza 2016.

54 Wolfgang Reinhard, Freunde und Kreaturen. "Verflechtung“ als Konzept zur Erforschung historischer Führungsruppen. Römische Oligarchie um 1600, München 1979; IDEM, Power Elites and State Building, Oxford 1996. 
on nobles at the Pobs court around the year 1600, he determined the existence of groups based on blood relations, friendship, regional nearness and patronage. $\mathrm{He}$ also imposed the theory of social networks on historical research, which he then used as a framework for reconstructing relationships. ${ }^{55}$ Polish researcher Antoni Mączak, whose publications have enjoyed a positive response, has extended the work by Asch and Reinhardt. ${ }^{56}$ Additional works from this school of thought have come from German historian Mark Hengerer, who has researched the court of the Emperor Ferdinand III and Karl VI. ${ }^{57}$

The concept of symbolic communication will be used as the second methodological view. Gerd Althoff and Barbara Stollberg-Rilinger, working at the University of Münster in the 1990s, pioneered this approach. ${ }^{58}$ This direction of historical inquiry takes its inspiration from works of cultural anthropology, sociology and phenomenology..$^{59}$ The concept of symbolic communication has helped researchers to discover how contemporaneous man can perceive rituals or ceremonies and how he can interpret the symbols during these festive events. The main object of interest in this field is in the means of verbal and nonverbal communication used for the transfer of information between two or more sides. From this point of view, symbols, gestures, metaphors and rituals play an important role as the media for communication. ${ }^{60}$

The third methodological view that will be used is historical anthropology, which tries to change the views on humans in history. Similar to the methods mentioned previously, it can be used to discover different perspectives of political history

55 Idem, Freunde und Kreaturen, p. 32-41.

56 Antoni Mączak (ed.), Klientelsysteme im Europa der frühen Neuzeit, München 1988; IDem, From Aristocrat Household to Princely Court: Restructuring Patronage in the Sixteenth and Seventeenth Centuries, in: R. G. Asch - A. M. Birke (edd.), Princess, patronage, and the nobility, p. 315-328; IDEM, Klientela Nieformalne systemy wladzy w Polsce I Europie XVI-XVIII w., Warszawa 1994.

57 Mark Hengerer, Kaiserhof und Adel in der Mitte des 17. Jahrbunderts. Eine Kommunikationsgeschichte der Macht in der Vormoderne, Konstanz 2004 (= Historische Kulturwissenschaft 3); IDEM, Kaiser Ferdinand III. 1608-1657. Eine Biographie, Wien 2012 (= Schriftenreihe der Kommission für Neuere Geschichte Österreichs 107).

58 Barbara Stollberg-Rilinger, Zeremoniell, Rituall, Symbol. Neue Forschungen zur symbolischen Kommunikation in Spätmittelalter und Früher Neuzeit, Zeitschrift für historische Forschung 27, 2000, p. 389-405; EADEm, Symbolische Kommunikation in der Vormoderne. Begriffe, Thesen, Forscbungsperspektiven, Zeitschrift für historische Forschung 31, 2004, p. 489-527; Barbara StollberG-RILinger - Tim Neu - Christina Brauner (edd.), Alles nur symbolish? Bilanz und Perspektiven der Erforschung symbolischer Kommunikation, Köln-Weimar-Wien 2013.

59 From cultural anthropology-inspirited symbolic communication, see Claude Lévi-Strauss, Clifford Geertz, Victor W. Turner; from sociology, see, for example, Pierre Bourdieu, Max Weber, Émile Durkheim and philosopher Ernst Cassier. B. Stollberg-Rilinger, Symbolische Kommunikation, 490-492.

IвIDEM. 
in the early modern period. ${ }^{61}$ This point of view is based on different sources and their interpretations. First, it calls for analysing personal correspondence and other personal memories, and then it reconstructs the individual world of the person, his thinking, feelings, and so on. It is also possible to find this type of construction in documents that once served only official needs. This methodology has opened a new direction in the research of diplomatic relationships, and historians are now beginning to explore other sides of diplomatic letters, in hopes of discovering new parts of history from other perspectives. ${ }^{62}$

The presented research intention continues in the vein of discovering international relationships between the Spanish monarchy and other European countries in the second half of the $17^{\text {th }}$ century. Similar to the work of Cristina Bravo Lozano and Enrique Corredera Nilson, it will focus on the connections between the Catholic monarchy and other culturally and religiously different countries. ${ }^{63}$ The research objects will be those belonging to the Electorate of Brandenburg-Prussia, the Duchy/Electorate of BraunschweigLüneburg and the Hanseatic League. They were selected on the basis of the quality and quantity of written sources, along with their similar political power in Europe, among other factors.

The reign of the Spanish king Charles II defines the project's boundaries, because, after his death, the entire distribution of power across Europe was transformed. ${ }^{64}$

61 Richard van Dülmen, Historická antropologie. Vývoj, problémy, úkoly, Praha 2002, p. 11-12. For comparison Gert Dressel, Wissenschaftpraxis - Biographien - Generationen. Ein paar Facetten einer Reflexien Historischen Anthropologie, in: Václav Bůžek - Dana Štefanová (edd.), Menschen - Handlungen - Strukturen. Historisch-anthropologische Zugangsweisen in den Geschichtswissenschaften, České Budějovice 2001 (= Opera historica 9), p. 27-69; Paolo Viazzo, Mapping the Territory of Historical Anthropology, in: ibidem, p. 7-25; Georg Iggers, Historiography in the Twentieth Century: From Scientific Objectivity to the Postmodern Challenge Epilogue, Weleyan 2005; Peter Burke, History and Social Theory, Cambridge 2005; Wojciech KęDzierzawski, Codzienność jako kategoria antropologiczna w perspektywie hostorii kultury, Opole 2009.

62 Thomas Nicklas, Macht - Politik - Diskurs. Möglichkeiten und Grenzen einer Politischen Kulturgeschichte, Archiv für Kulturgeschichte 86, 2004, p. 1-23. For Comparison for example Heidrum Kugeler - Christian Sepp - Georg Wolf (edd.), Internationale Beziehungen in der Frühen Neuzeit, Münster 2006; Hans-Christof Kraus - Thomas Nicklas (edd.), Geschichte der Politik. Alte und neue Wege, München 2007.

63 Cristina Bravo Lozano focused mainly on the Spanish diplomats in the British Isles (1660-1702). Cristina Bravo Lozano, Tierras de misión. La politica confesional de la Monarquía de España en Las Islas Británicas, 1660-1702, Madrid 2014 (PhD Thesis). On the other hand Enrique Corredera Nilson has written about the connection between the Spanish Empire and Sweden. Enrique CoRredera Nilson, Todos somos godos. Las relaciones hispano-suecas desde la década de 1640 hasta la Paz de Oliva, Madrid 2009.

64 In General Jeremy BLACK, Eighteenth Century Europe: 1700-1789, New York 1990. Works connected with Spanish history, Henry A. Kamen, The War of Succession in Spain 1700-1715, London 1969; IDEm, Philip V. of Spain: The King who Reigned Twice, New Haven 2001. 
The situation in the Holy Roman Empire perceptibly changed in the second half of the $17^{\text {th }}$ century because the Elector of Brandenburg-Prussia slowly increased his power to become a new king in Europe. ${ }^{65}$ This period was an important era for the creation of the diplomatic system of the Holy Roman Empire after the year 1648. ${ }^{66}$ The biggest turn was the changing borders of the Holy Roman Empire and escalating to the highest scene of European politics. From the side of the Spanish king, the selected time period signified the end of the Habsburgs in Spain and their last effort to continue in the glorious legacy of Charles V. ${ }^{67}$

The geographical borders of the research were based on the relatively geographic proximity of northern parts of the Holy Roman Empire to the Spanish Netherlands. The second geographic criterion was the Protestant religion, which appealed mostly to people from northern and Central Europe. The geographic position of the Electorate of Brandenburg-Prussia, the Duchy/Electorate of Braunschweig-Lüneburg and the Hanseatic League had an influence on their diplomatic direction. The strong influences of France and Sweden in the area forced others to look for powerful allies, especially because the Habsburg army was situated more to the east during times of important fighting with the Ottoman Empire. ${ }^{68}$ On the other hand, the Spanish monarchy was not strong enough to conquer other territories, and vice versa. Similar to its allies, Spain was pressured to defend its own property. ${ }^{69}$

The attributes of the Electorate of Brandenburg-Prussia and the Duchy/ Electorate of Braunschweig-Lüneburg, along with historical circumstances, predestined them to expand their positions inside the Holy Roman Empire. In addition, they were connected in terms of religion, which still claimed an important argument in the politics of the second half

65 Closer in Michael Hughes, Early Modern Germany, 1477-1806, Philadelphia 1992; Christopher M. Clark, Iron Kingdom: the Rise and Downfall of Prussia 1600-1947, Cambridge 2006.

66 For more about research of the diplomacy in early modern period, see Garrett Mattingly, Renaissance Diplomacy, Cambridge 1955; William Roosen, Early Modern Diplomatic Ceremonial. A Systems Approach, The Journal of Modern History 52, 1980, p. 452-476; Anuschka Tischer, Französische Diplomatie und Diplomaten auf dem Westfälischen Friedenskongreß. Außenpolitik unter Richelieu und Mazarin, Münster, 1999; Hillard von Thiessen, Diplomatie und Patronage. Die spanisch-römischen Beziehungen 1605-1621 in akteurszentrierter Perspektive, Epfendorf 2010.

67 Closer to the situation in the mentioned area in, for example, Klaus MüLler, Das kaiserliche Gesandtschaftswesen im Jahrbundert nach dem Westfälischen Frieden (1648-1740), Bonn 1976; Henry A. Kamen, Spain in the Later Seventeenth Century, London 1980.

68 Rhoads Murphey, Ottoman Warfare, 1500-1700, London 2001, p. 9-12.

69 Closer to the situation in the mentioned area in, for example, Paul Sonnino, Louis XIV. and the Origins of the Dutch War, Cambridge 1988; Peter Burke, Die Inszenierung des Sonnenkönigs, Berlin 1993; Heinz Schilling, Höfe und Allianzen - Deutschland 1648-1763, Berlin 1998; John A. Lynn, The Wars of Louis XIV 1667-1714, London 1999. 
of the $17^{\text {th }}$ century and had an influence on the affairs of the early modern world. Both of these parts of the Holy Roman Empire were Protestant, yet they supported the Spanish monarchy in military campaigns to balance the French and Swedish influences in the area. ${ }^{70}$ For this service, the Spanish government periodically had to send money to cover soldiers' salaries, among other things. However, during the reign of Charles II, the Spanish allies were not paid on time. For this reason, the envoys of both these electorates were obligated to travel to Madrid in an effort to get the promised money. ${ }^{71}$ Later, these agents informed their rulers not only about their negotiations, but also about the affairs of the Spanish court in Madrid. To ensure the success of their missions, they needed to create their own social and information networks, the reconstructions of which will become an important part of the doctoral thesis.
In opposition to the electorates, the second half of the project will focus on the relationships between the Spanish monarchy and the Hanseatic League. ${ }^{72}$ This type of relationship was based on commerce, which was also connected to military relations, because it was the source of Spanish wealth. The importance of this connection proved that the Hanseatic League had two agents in the Spanish areas of Madrid/ Seville and Cadiz. ${ }^{73}$ Because they were living and mainly working in Spain, it was important for them, more than for others, to have their own social networks within the confines of the Spanish monarchy. Similar to other agents, envoys or ambassadors, they sent messages of new affairs from Madrid or other parts of the Spanish Empire periodically. ${ }^{74}$ In this case, the object of the research will be the reconstruction of these social connections and the perception of the Spanish world from their points of view.

70 Margaret Shennan, The Rise of Brandenburg-Prussia, 1618-1740, London 1995, p. 25.

71 Gustav Adolf Harald Stenzel, Geschichte der europäischen Staaten, Geschichte des preussischen Staats II, Hamburg 1837, p. 370.

72 Margrit Schulte BeerbüHl, Networks of the Hanseatic League, Mainz 2012; Gisela Graichen Rolf Hammel-Kiesow - Alexander Hesse, Die deutsche Hanse: Eine heimliche Supermacht, Reinbek 2013.

73 Manuel Herrero SÁnchez, Foreign Communities in the Cities of the Catholic Monarchy: A Comparative Perspective between the Overseas Dominions and the Crown of Castile, in: Harald E. Braun - Jesús Pérez-Magallón (edd.), The Transatlantic Hispanic Baroque: Complex Identities in the Atlantic World, Farnham-Burlington 2016, p. 198-199.

74 Closer to diplomatic sources in general Beatrix BAstL, Formen und Gattungen frühneuzeitlicher Briefe, in: J. Pauser - M. Scheutz - T. Winkelbauer (edd.), Quellenkunde der Habsburgermonarchie, p. 801-812; Friedrich Edelmayer, Gesandschaftsberichte in der Frühen Neuzeit, in: ibidem, p. 849-859; Irene BALdRIga, The Role of Correspondence in the Transmission of Collecting Patterns in Seventeenth-Century Europe: Models, Media and Main Characters, in: Robert Muchembled (ed.), Cultural Exchange in Early Modern Europe III. Correspondence and Cultural Exchange in Europe 1400-1700, Cambridge 2007, p. 187-216; Carmen Furger, Briefsteller: Das Medium ,Brieff“ im 17. und frühen 18. Jahrhundert, Köln 2010. 
The intended research will be focused along two different lines, with which are associated two different hypotheses. First, the more general, will clarify which researched countries in the relationships with the Spanish monarchy were, in fact, the main rulers in mutual relationships and the main initiators of political actions in the regions under study. From this standpoint, we can pose several questions. Which strategies did both sides use during the negotiation of important contracts? How did they keep their promises? Alternatively, what did they do to keep them? Were their agreements unilateral or bilateral? ${ }^{75}$

The second important part of the project will show the connection between the Spanish aristocracies and the German world, together with the mutual percep- tion of both groups of noblemen. ${ }^{76}$ This section will demonstrate that the Spanish court probably comprised a group of nobles who were active in supporting the conquest struggles of the Electorate of Brandenburg-Prussia and other political actions of other elected countries in the mentioned territory. ${ }^{77}$ The need for the existence of the German faction will be explained in the context of the competition between the mother of the Spanish king Charles II, Mariana of Austria (1634-1696), and his uncle, John of Austria the Younger (1629-1679). Philip IV's brother looked for glory in war, while his sister-in-law advanced the interests of the Austrian Habsburgs. ${ }^{78}$

This is also connected the problem of these agents' social networks and rela-

75 The author takes his inspiration from American scholar Henry Kissinger and his theory of power. For more information, see Henry Kissinger, Diplomacy, New York 1994.

76 In general Albrecht Classen, Das Fremde und das Eigene, in: Peter Dienzelbacher (ed.), Europäische Mentalitätsgeschichte. Hauptthemen in Einzeldarstellungen, Stuttgart 1993, p. 429-450; R. vAN Dülmen, Historická antropologie, p. 73; Lud’a Klusáková - Markéta KŘížová - Karel Kubiš - Miloš Rezník, Namisto uivodu. „My" a „oni“- nácrt teoretické reflexe problematiky, in: Karel Kubiš (ed.), Obraz druhého v historické perspektivě II. Identity a stereotypy př̀i formování moderní společnosti, Praha 2003, p. 11-28; Arno Strohmeyer, Wahrnemnungen des Fremden. Differenzerfahrungen von Diplomaten im 16. und 17. Jahrbundert. Forschungsstand - Erträge - Perspektiven, in: Michael Rohrschneider - Arno Strohmeyer (edd.), Wahrnehmung des Fremden. Differenzerfahrungen von Diplomaten im 16. und 17. Jahrhundert, Münster 2007, p. 3. For more information about the perception of the Spanish, see Rostislav Smíšex, Dĩvèra nebo nenávist? Obraz Španèla v korespondenci cisaře Leopolda I. s knižetem Ferdinandem z Dietrichsteina, Časopis Matice moravské 123, 2004, p. 47-76; IDEM, "Quod genus hoc hominum": Margarita Teresa de Austria y su corte española en los ojos de los observadores contemporáneos, in: J. Martínez Millán - R. González Cuerva (edd.), La Dinastía de los Austria II, s. 909-952; IDEM, Středni Evropa a Španèlsko v polovinè 17. století. Markéta Tereza Španélská a její španèlský hofstát očima soudobých pozorovatelü, Český časopis historický 109, 2011, p. 397-341.

77 M. Shennan, The Rise, p. 25.

78 Regarding competition at the Spanish court of Carlos II, for example José Calvo Poyato, Juan José de Austria, Barcelona 2003; L. Oliván Santaliestra, Mariana de Austria; Antonio ÁlvarezOssorio Alvariño, Precedencia ceremonial y dirección del gobierno. El ascenso ministerial de Fernando de Valenzuela en la corte de Carlos II, in: Bernardo J. García García - Antonio Álvarez-Ossorio Alvariño (edd.), Vísperas de sucesión, Europa y la Monarquía de Carlos II, Madrid 2015, p. 21-56. 
tions inside the organism of the court. First, the author will be solving a problem about the attributes that affected the diplomats' social networks. Was the language used important for creating these connections? Did all German nobles belong to one group of nobles with the same target? What was more important in diplomatic relationships, religion or the achievement of an aim? How did the members of the Spanish court react to Protestant diplomats? Could the Protestant religion be a barrier during negotiations or everyday life? Or was there any problem with cooperation between Protestant and Catholic diplomats? From these crucial questions should come the answer to the question of the most determining factor for a nobleman in diplomatic service at the Habsburgs' court in Madrid. This comparison will show the practical characterisation of value scale, which could influence the success of diplomatic missions. ${ }^{79}$ This portion of the project will answer questions about the perception of the Spanish court and its members in the eyes of foreign noblemen, which will show the differences between the cultures of Spain and Central Europe. This perception will broaden with the examination of the
Austrian ambassadors in the service of the Emperor Leopold I.

The next topic addressed will be the important question regarding the hierarchical position of German-speaking diplomats at the Spanish court in Madrid. The components used to answer this question will primarily be an analysis of the ceremonies in which the diplomats from the Holy Roman Empire participated. In the early modern age, the festive entrances of ambassadors, diplomats and envoys played an important role in their representation. ${ }^{80} \mathrm{~A}$ comparison between the different diplomatic entrances will show their symbolic status at the court in Madrid in the context of Spanish relationships with other countries and how the Spanish perceived the political power of their allies and enemies. ${ }^{81}$

The crucial questions will be answered based on an extended analysis of diplomatic documents, which could possibly be divided in two main groups. The first one includes official diplomatic relations between the Spanish monarchy and the northern parts of the Holy Roman Empire (the Electorate of Brandenburg-Prussia, the Duchy/Electorate Braunschweig-Lüneburg and the Hanseatic League). These documents can be found in the General

79 The author takes his inspiration from the fields of sociology, especially from French scholar Pierre Bourdieu and his theory of symbolic capital. For more information, see Pierre Bourdieu, Distinction: A Social Critique of the Judgement of Taste, Cambridge 1984.

80 W. Roosen, Early Modern Diplomatic Ceremonial, p. 464-465; J. R. Mulryne - Maria Ines Aliverti - Anna Maria Testaverde (edd.), Ceremonial Entries in Early Modern Europe: The Iconography of Power, Farnham-Burlington 2015.

81 W. Roosen, Early Modern Diplomatic Ceremonial, p. 464-465.

82 Geheimes Staatsarchiv Preußischer Kulturbesitz, I. HA GR, Rep. 63, Nr. 478-492. 
Archive in Simancas, the Prussian Secret State Archives in Berlin, the Archive of Lower Saxony in Hannover and the Archive of Hanseatic City in Lübeck. They will be used primarily for a reconstruction of the content of the international relationships between the Spanish monarchy and the other mentioned objects.

From the second group, the correspondence and the instructions left by diplomats from the Holy Roman Empire will reveal the answer to the most important part of the proposed research, that which is aimed at the view of humans during the early modern age. First, the emphasis will fall on the mission of Melchior von Ruck, from 1677 to 1681, in Madrid. ${ }^{82}$ From these messages in Berlin, it is possible to reconstruct not only the negotiations between the Spanish king and the Elector of Brandenburg, but also to describe the second reign of Don Juan the Younger and the situation during the last years of his life. ${ }^{83}$ Very similarly, other sources now located in the archives in Hannover will be used for the analysis of Abbé Luigi Ballati and his stay at the Spanish court. ${ }^{84}$ Slightly different will be the work with the records of the ambassadors from the Hanseatic League, because their diplomats were situated permanently in Spain. ${ }^{85}$ This last third should reveal more about the collaboration and connections in the field of business and also uncover the social network of the Hanseatic League at the court of Charles II. ${ }^{86}$ The last of the most important sources are deposited in Vienna, in the Haus-, Hof- und Staatsarchiv. The Habsburg ambassadors' letters in Madrid include discussions of international politics, and they may also reveal information about the position and relations between the Emperor and the regions of the Holy Roman Empire. ${ }^{87}$

The presented research, focused on diplomatic relationships between the

83 For more information, see Josefina Castillo Soto, Don Juan José de Austria (bijo bastardo de Felipe IV): su labor politica y militar, Madrid 1992; Albrecht Kalnein, Juan José de Austria en la España de Carlos II: historia de una regencia, Madrid 2001; J. Calvo Poyato, Juan José de Austria; Elvira González Asenjo, Don Juan José de Austria y las Artes 1629-1679, Madrid 2006; Ignacio Ruiz RoDRíguez, Don José de Austria en la monarquía hispánica: entre la política, el poder y la intriga, Madrid 2007.

84 Niedersächsisches Landesarchiv Hannover, Cal. Br 24, Nr. 7699/3.

85 Archiv der Hansestadt Lübeck, Altes Senatsarchiv, Hispanica (Spanien) 72-74.

86 For more about relationships between the Spanish monarchy and the Hanseatic League during the early modern period, see Thomas Weller, Las repúblicas mercantiles y e sistema imperial hispánico: Génova, las Provincias Unidas y la Hansa, in: Manuel Herrero Sánchez - Yasmina Rocío Ben Yessef Garfia - Carlo Bittossi - Dino Puncuh (edd.), Génova y la monarquía hispánica (1528-1713), Madrid 2011, p. 627-656; IDEM, Entre dos aguas: la Hansa y sus relaciones con la Monarquía Hispánica y las Provincias Unidas en las primeras décadas del siglo XVII, in: Bernardo J. García García (ed.), E1 arte de la prudencia. La tregua de los Doce Años en la Europa de los Pacificadores, 1598-1618, Madrid 2012, p. 179-199.

87 Haus-, Hof- und Staatsarchiv Wien, Diplomatie und Außenpolitik vor 1848, Außerdeutsche Staaten, Spanien, Hofkorrespondenz 7; Haus-, Hof- und Staatsarchiv Wien, Diplomatie und Außenpolitik vor 1848, Außerdeutsche Staaten, Spanien, Diplomatische Korrespondenz 46-59. 
Spanish monarchy and the northern parts of the Holy Roman Empire, belongs, except for small exceptions, to an unexplored field. The reason for this unclassified state lies, mostly, in the language barrier; however, the planned project should break this imaginary wall and show the connections of two different worlds. The Spanish attendance in the Netherlands, where their influence was common, formed a spirit of necessary cooperation that could change the cycle of European history. ${ }^{88}$ The intent is to follow the work of the previous generations of European historians and to interconnect the history of Central Europe with the history of the Spanish monarchy through the present day. On the other hand, the author will continue the work of Spanish researchers who have studied the diplomatic relationships of the Spanish Empire during the second half of the $17^{\text {th }}$ century. The use of new methodologies will help the author to answer these new questions, which have come together with newer historical views.

88 See more in Manuel Herrero Sánchez - Ana Crespo Solana (edd.), España y las 17 provincias de los Paises Bajos: una revisión historiográfica (XVI-XVIII), Córdoba 2002. 
Ondřej Stolička

Diplomatic relations between the Spanish monarchy and the northern parts of the Holy Roman Empire during the reign of Charles II. Doctoral project (Abstract)

The presented study introduces theses of doctoral project focused on extending the knowledge of international relations between the Monarchy of Spain and northern parts of the Holy Roman Empire - Brandenburg-Preußen, Braunschweig-Lünenburg, the Hansa towns - during the reign of Charles II. The author will research the formations of social networks at Madrid Royal Court on the basis of diplomatic activities of particular imperial emissaries to Madrid. There will not be neglected also questioning the existence of so called "German" faction at the court and outlining the cooperation among the mentioned emissaries and ambassadors of Leopold I of Habsburg. Contemporaneously, the author will concern about the way in which the noblemen from the Holy Roman Empire reflected their long-term stay on the Iberian Peninsula. There will further be researched social and ceremonial performances which the mentioned persons participated in regularly. In its heuristic stage the author will use rich source bases, especially documents preserved in Geheimes Staatsarchiv Preußischer Kulturbesitz Berlin, Niedersächsisches Landesarchiv Hannover, Archiv der Hansestadt Lübeck, Archivo General de Simancas, Haus- Hof- und Staatsarchiv Wien.

KEYWORDS:

Diplomatic relations; 17th century; Spanish monarchy; Northern parts of the Holy Roman Empire; Diplomats 